\title{
Epidemiological and pathologic aspects of extra-skeletal osteosarcoma in dogs
}

\section{Aspectos epidemiológicos e patológicos do osteossarcoma extraesquelético em cães}

\author{
Tainã Normanton Guim ${ }^{1}$; Bianca Santana de $\mathrm{Cecco}^{1}$; Cláudio João Mourão \\ Laisse $^{2}$; Bernardo Schmitt ${ }^{1}$; Luan Cleber Henker ${ }^{1}$; Camila da Rosa Vieira ${ }^{3}$; David \\ Driemeier ${ }^{4}$; Saulo Petinatti Pavarini' ${ }^{4}$ Luciana Sonne ${ }^{4 *}$
}

\begin{abstract}
Extra-skeletal osteosarcoma is a malignant mesenchymal neoplasm that originates from soft tissue. This tumor occurs spontaneously in dogs, but there are few cases described in the literature. The objective of this study was to describe the epidemiological and pathologic features of extra-skeletal osteosarcoma in 36 dogs. Cases diagnosed as osteosarcoma affecting dogs ( $\mathrm{n}=216$ ), during 2006 to 2016 were reviewed. Of these, 36 cases were diagnosed as extra-skeletal osteosarcoma. The mean age of affected dogs was 10.4 years, and the mean weight was $19.5 \mathrm{~kg}$. No breed predisposition was observed. The most frequently affected sites were the mammary glands $(80.6 \% ; 29 / 36)$, subcutaneous tissue $(5.6 \% ; 2 / 36)$, liver $(5.6 \%$; $2 / 36)$, spleen $(2.8 \% ; 1 / 36)$, omentum $(2.8 \% ; 1 / 36)$, and kidney $(2.8 \% ; 1 / 36)$. Histological examination revealed that $61.1 \%(22 / 36)$ of the tumors were osteoblastic, 33.3\% (12/36) chondroblastic, $2.8 \%(1 / 36)$ fibroblastic, and $2.8 \%(1 / 36)$ were giant cell-rich osteosarcomas. Histological grade II and III were the most frequent. Lymph node metastases were observed in $21.4 \%$ (3/14) of the cases of mammary gland osteosarcoma. Distant metastases were observed in $23.1 \%$ (3/13) of cases by diagnostic imaging and in $71.4 \%(5 / 7)$ during autopsy. Metastases were observed in the lungs $(57.1 \% ; 4 / 7)$, liver $(14.3 \% ; 1 / 7)$, spleen $(14.3 \% ; 1 / 7)$, and in multiple sites $(14.3 \% ; 1 / 7)$. Pulmonary metastases were more frequently observed in cases of mammary gland osteosarcoma.
\end{abstract}

Key words: Mammary gland. Neoplasms Sarcomas. Soft tissues.

\section{Resumo}

Osteossarcoma extraesquelético é uma neoplasma mesenquimal maligno que se origina de tecidos moles. O neoplasma ocorre espontaneamente em cães, mas há poucos casos descritos na literatura. Este trabalho teve como objetivo descrever os aspectos epidemiológicos e patológicos do osteossarcoma extraesquelético em 36 cães. Casos diagnosticados de osteossarcoma afetando cães (n=216), durante 2006 a 2016 foram revisados. Deste total, 36 casos tiveram diagnóstico de osteossarcoma extraesquelético. A média de idade foi de 10,4 anos, não houve predisposição racial e o peso médio foi de 19,5kg. Os locais acometidos foram glândula mamária $(80,6 \% ; 29 / 36)$, tecido subcutâneo $(5,6 \% ; 2 / 36)$, fígado $(5,6 \%$;

1 Discentes, Curso de Doutorado, Universidade Federal do Rio Grande do Sul, UFRGS, Porto Alegre, RS, Brasil. E-mail: tainanormanton@hotmail.com; biasantanacecco@gmail.com; bernardoschmitt@msn.com; henkerluan@hotmail.com

2 Prof. Dr., Universidade Eduardo Mondlane, FC/UEM, Maputo, MZ, África. E-mail: claudiolaisse@yahoo.com.br

3 Discente, Curso de Graduação, Universidade Federal do Rio Grande do Sul, UFRGS, Porto Alegre, RS, Brasil. E-mail: v-camila2006@hotmail.com

4 Profs. Drs., UFRGS, Porto Alegre, RS, Brasil. E-mail: davetpat@ufrgs.br; sauloppvet@yahoo.com.br; lusonne@yahoo.com.br

* Author for correspondence 
$2 / 36)$, baço $(2,8 \% ; 1 / 36)$, omento $(2,8 \% ; 1 / 36)$ e rim $(2,8 \% ; 1 / 36)$. Na histologia, $61,1 \%(22 / 36)$ eram osteoblásticos, 33,3\% (12/36) eram condroblásticos, 2,8\% (1/36) eram fibroblásticos e 2,8\% (1/36) eram ricos em células gigantes. Os graus histológicos II e III foram os mais frequentes. Metástases nodais estavam presentes em 21,4\% (3/14) dos casos que ocorreram na mama. Metástases distantes foram constatadas em $23,1 \%$ (3/13) dos casos por exames de imagem e em 71,4\% (5/7) dos casos pela autópsia. Os locais de metástases foram pulmões $(57,1 \%$; 4/7), fígado $(14,3 \% ; 1 / 7)$, baço $(14,3 \%$; $1 / 7)$ e em múltiplos sítios $(14,3 \%$; 1/7). Metástases pulmonares foram mais frequentes em cadelas comosteossarcoma de glândula mamária.

Palavras-chave: Glândula mamária. Neoplasmas. Sarcomas. Tecidos moles.

\section{Introduction}

Extra-skeletal osteosarcoma is a soft tissue neoplasm characterized by the proliferation of malignant mesenchymal cells which produce bone matrix or woven bone, with no involvement of osseous tissue or adjacent periosteum (THOMPSON; DITTMER, 2017). Such tumor is rare, and it has been mainly reported in humans, dogs and cats (PATNAIK, 1990; LEE et al., 1995; SPUGNINI et al., 2001). The main anatomic sites reported are the mammary gland, spleen, liver, skin, subcutaneous tissue, as well as organs of the gastrointestinal and urinary tracts (LANGENBACH et al., 1998).

Extra-skeletal osteosarcomas present highly malignant biological traits and frequently metastasize. The affected dogs frequently have unfavorable prognosis, and present shorter survival time when compared with dogs diagnosed with skeletal osteosarcomas, due to factors including late detection in cases of intra-abdominal tumors, as well as limited surgical procedures for certain anatomic sites (THOMPSON; DITTMER, 2017). Metastases are usually observed in the lymph nodes and liver (PATNAIK, 1990); metastases are not frequent in the lungs (THOMPSON; DITTMER, 2017). Death usually results from tumor recurrence or euthanasia at the time of diagnosis (LANGENBACH et al., 1998; THOMPSON; DITTMER, 2017).

Studies involving the main aspects of extraskeletal osteosarcomas in dogs are scarce (PATNAIK, 1990; KUNTZ et al., 1998; LANGENBACH et al., 1998), and most descriptions are represented by individual case reports. Despite its rare occurrence, this tumor arises spontaneously in dogs, and presents an apparently distinct biological behavior when compared with skeletal osteosarcomas on which broader information is available. In addition, although the histopathologic features of extra-skeletal osteosarcoma have been previously reported, no standardized histological patterns were established. Therefore, the present study described the epidemiological characteristics, gross and microscopic findings of extra-skeletal osteosarcomas in dogs.

\section{Material and Methods}

A retrospective study was performed at the database of the Department of Veterinary Pathology of the Universidade Federal do Rio Grande do Sul (UFRGS). Autopsy and biopsy reports were reviewed, and all cases of extra-skeletal osteosarcomas diagnosed between 2006 and 2016 were compiled. Analyzed samples included cases of osteosarcomas located in soft tissues, which showed no clinical, radiographical or gross evidence or primary skeletal involvement (bone tissue or periosteum). All cases were confirmed through histopathologic examination.

Epidemiological aspects (breed, body weight, sex, age, and anatomic site), clinical, gross and microscopic findings were obtained from the autopsy and biopsy report files, as well as from the clinical records and through phone calls with the referring small animal clinicians. 
Formalin-fixed paraffin-embedded tissue blocks were selected to conduct the histopathologic evaluation, and tissue sections $(3 \mu \mathrm{m})$ were routinely stained by hematoxylin and eosin (HE) to re-evaluate the neoplasm. Cases with no available tissue sections for reevaluation were excluded from the present study. Tumors were classified according to the predominant histological pattern as osteoblastic (productive and nonproductive), chondroblastic, fibroblastic, poorly differentiated, telangiectatic, and giant cell-rich osteosarcomas (SLAYTER et al., 1994).

The osteosarcoma histological grade was established through scores given to the degree of nuclear pleomorphism, percentage of intratumoral necrosis, and mitotic index. The latter was determined in 10 randomly assigned high power fields (400X), which included the tumor center and periphery. The final scores varied from 1 to 10 and these values were then converted to histological grades I, II, and III, according to previous literature (LOUKOPOULOS; ROBINSON, 2007).

The diagnosis of mammary gland osteosarcoma was established through the histological identification of malign bone component associated with normal glandular epithelium. A thorough examination was applied to the epithelial component to rule out mammary gland mixed tumors.

Data regarding previous malign bone neoplasia as well as mammary gland mixed tumors affecting these dogs was obtained in order to exclude the possibility of a metastatic neoplasm. The possibility of any primary bone lesion as well as metastases from other tumors was conducted through evaluation of clinical data, in addition to radiographic and autopsy findings. In order to distinguish between the tumor primary and secondary (metastatic) site, information regarding the organ of first chronologic diagnosis and tumor size were considered.

\section{Results}

During the period evaluated, 216 osteosarcomas were diagnosed in dogs, of which, 16.7\% (36/216) were extra-skeletal osteosarcomas (Table 1). The ages of the affected dogs were available for $83.3 \%$ (30/36), and ranged from 6 to 16 years, with mean and median age of 10.4 and 10 years, respectively. Relative to breed predominance, mixed breed dogs were overrepresented $\quad(45.7 \% ; 16 / 35)$,followed by the German Shepherd $(8.6 \% ; 3 / 35)$, Poodle (8.6\%;3/35), Labrador Retriever (5.7\%;2/35), English Cocker Spaniel $(5.7 \% ; 2 / 35)$, Dachshund (5.7\%;2/35), Pinscher $(5.7 \% ; 2 / 35)$, Rottweiler $(5.7 \% ; 2 / 35), \quad$ Boxer $\quad(2.9 \% ; 1 / 35), \quad$ Bulldog $(2.9 \% ; 1 / 35)$, and Akita Inu $(2.9 \% ; 1 / 35)$. The breed of one dog was not available. Body weight data was obtained from $36.1 \%(13 / 36)$ of these dogs, and ranged from 2.3 to $38 \mathrm{~kg}$, with mean and median values of $19.5 \mathrm{~kg}$ and $18 \mathrm{~kg}$, respectively. Most of the affected dogs were female $(83.3 \% ; 30 / 36)$, and males were underrepresented $(16.7 \% ; 6 / 36)$.

Primary extra-skeletal osteosarcomas occurred in the mammary gland $(80.6 \% ; 29 / 36)$, liver $(5.6 \%$; $2 / 36)$, subcutaneous tissue $(5.6 \% ; 2 / 36)$, spleen $(2.8 \% ; 1 / 36)$, kidney $(2.8 \% ; 1 / 36)$, and omentum $(2.8 \% ; 1 / 36)$. Mammary gland osteosarcomas were detected in the abdominal $(42.9 \% ; 9 / 21)$, thoracic $(19 \% ; 4 / 21)$, inguinal $(9.5 \% ; 2 / 21)$, and in multiple mammary glands concomitantly $(28.6 \% ; 6 / 21)$. In eight cases the information regarding the location of the neoplasm in the mammary gland was not available.

Grossly, extra-skeletal osteosarcomas were represented by nodules or masses, with size ranging from 2.5 to $35 \mathrm{~cm}$ in diameter (Figure $1 \mathrm{~A}-1 \mathrm{D}$ ). At the sectioned surface, tumors were whitish, with firm to hard consistency, and sometimes were associated with multifocal areas of necrosis and hemorrhage. Skin ulceration was observed in some cases of mammary gland osteosarcoma $(43.8 \% ; 7 / 16)$. 
Table 1. Cases of extra-skeletal osteosarcoma affecting dogs diagnosed atthe Department of Veterinary Pathology UFRGS (2006-2016).

\begin{tabular}{|c|c|c|c|c|c|c|c|c|c|c|}
\hline Cases & Breed & $\begin{array}{l}\text { Age } \\
\text { (Years) }\end{array}$ & Sex & $\begin{array}{c}\text { Bo- } \\
\text { dyweight } \\
(\mathrm{kg})\end{array}$ & $\begin{array}{l}\text { Anatomic } \\
\text { site }\end{array}$ & $\begin{array}{l}\text { Histologicsub- } \\
\text { type }\end{array}$ & Grade & $\begin{array}{l}\text { Vascular } \\
\text { invasion }\end{array}$ & $\begin{array}{l}\text { Lymph } \\
\text { node } \\
\text { metas- } \\
\text { tases }\end{array}$ & $\begin{array}{l}\text { Distantme- } \\
\text { tastases }\end{array}$ \\
\hline 1 & $\begin{array}{l}\text { Mixed } \\
\text { breed }\end{array}$ & 8 & F & - & MG & Osteoblastic & III & No & No & - \\
\hline 2 & $\begin{array}{l}\text { Mixed } \\
\text { breed }\end{array}$ & 10 & F & - & MG & Chondroblastic & III & No & - & - \\
\hline 3 & Poodle & 9 & $\mathrm{~F}$ & - & MG & Chondroblastic & I & No & - & - \\
\hline 4 & Poodle & 9 & F & - & MG & Osteoblastic & III & No & - & - \\
\hline 5 & $\begin{array}{l}\text { Cocker } \\
\text { Spaniel }\end{array}$ & 14 & F & - & MG & Chondroblastic & III & No & - & - \\
\hline 6 & $\begin{array}{l}\text { Mixed } \\
\text { breed }\end{array}$ & 9 & $\mathrm{~F}$ & - & $\mathrm{MG}$ & Osteoblastic & III & No & - & - \\
\hline 7 & $\begin{array}{l}\text { German } \\
\text { Shepherd }\end{array}$ & 14 & $\mathrm{~F}$ & - & MG & Chondroblastic & II & No & - & Lungs $^{(a)}$ \\
\hline 8 & $\begin{array}{l}\text { German } \\
\text { Shepherd }\end{array}$ & 9 & F & - & MG & Osteoblastic & II & No & - & - \\
\hline 9 & $\begin{array}{l}\text { Mixed } \\
\text { breed }\end{array}$ & 11.6 & $\mathrm{~F}$ & 12.2 & MG & Osteoblastic & III & No & No & $\mathrm{No}^{(\mathrm{a})}$ \\
\hline 10 & $\begin{array}{l}\text { Mixed } \\
\text { breed }\end{array}$ & 9 & $\mathrm{~F}$ & 20.4 & MG & Chondroblastic & II & No & - & $\mathrm{No}^{(\mathrm{a})}$ \\
\hline 11 & $\begin{array}{l}\text { Mixed } \\
\text { breed }\end{array}$ & - & $\mathrm{F}$ & 15 & MG & Chondroblastic & II & No & - & $\mathrm{No}^{(\mathrm{a})}$ \\
\hline 12 & $\begin{array}{l}\text { Mixed } \\
\text { breed }\end{array}$ & 10 & F & - & MG & Osteoblastic & III & No & Yes & - \\
\hline 13 & $\begin{array}{l}\text { German } \\
\text { Shepherd }\end{array}$ & 11 & $\mathrm{~F}$ & 44.3 & MG & Fibroblastic & II & No & No & $\mathrm{No}^{(\mathrm{a})}$ \\
\hline 14 & Boxer & 7 & F & - & MG & Osteoblastic & II & No & No & - \\
\hline 15 & $\begin{array}{l}\text { Mixed } \\
\text { breed }\end{array}$ & - & F & - & MG & Chondroblastic & II & No & - & - \\
\hline 16 & $\begin{array}{c}\text { Da- } \\
\text { chshund }\end{array}$ & 11 & $\mathrm{~F}$ & - & MG & Osteoblastic & III & Yes & No & - \\
\hline 17 & Poodle & 11 & $\mathrm{~F}$ & 2.3 & MG & Osteoblastic & III & No & No & Lungs $^{(a)}$ \\
\hline 18 & $\begin{array}{l}\text { Cocker } \\
\text { Spaniel }\end{array}$ & 9 & F & 10.6 & $\mathrm{MG}$ & Osteoblastic & III & Yes & Yes & $\mathrm{No}^{(\mathrm{a})}$ \\
\hline 19 & Bulldog & 12 & $\mathrm{~F}$ & 18 & MG & Osteoblastic & II & Yes & No & $\mathrm{No}^{(\mathrm{a})}$ \\
\hline 20 & $\begin{array}{l}\text { Mixed } \\
\text { breed }\end{array}$ & - & $\mathrm{F}$ & - & MG & Osteoblastic & II & Yes & - & - \\
\hline 21 & NI & 14 & $\mathrm{~F}$ & - & MG & Osteoblastic & III & No & No & - \\
\hline 22 & $\begin{array}{l}\text { Mixed } \\
\text { breed }\end{array}$ & 10 & $\mathrm{~F}$ & 5.6 & MG & Giantcell-rich & III & No & - & $\mathrm{No}^{(\mathrm{a})}$ \\
\hline 23 & Pinscher & 10 & F & - & MG & Osteoblastic & I & No & - & $\mathrm{No}^{(\mathrm{a})}$ \\
\hline
\end{tabular}


continuation

\begin{tabular}{|c|c|c|c|c|c|c|c|c|c|c|}
\hline 24 & $\begin{array}{l}\text { Mixed } \\
\text { breed }\end{array}$ & 11 & $\mathrm{~F}$ & 6.2 & MG & Chondroblastic & II & No & No & $\mathrm{No}^{(\mathrm{a})}$ \\
\hline 25 & Pinscher & 13 & $\mathrm{~F}$ & - & $\mathrm{MG}$ & Osteoblastic & III & Yes & Yes & $\begin{array}{l}\text { Lungs and } \\
\text { pancreas }^{(b)}\end{array}$ \\
\hline 26 & $\begin{array}{l}\text { Rot- } \\
\text { tweiler }\end{array}$ & 6 & $\mathrm{~F}$ & 36.6 & MG & Chondroblastic & II & No & No & - \\
\hline 27 & $\begin{array}{c}\text { Da- } \\
\text { chshund }\end{array}$ & 12 & $\mathrm{~F}$ & - & $\mathrm{MG}$ & Chondroblastic & II & No & No & - \\
\hline 28 & $\begin{array}{l}\text { Mixed } \\
\text { breed }\end{array}$ & - & $\mathrm{F}$ & - & MG & Osteoblastic & III & Yes & - & $\operatorname{Lungs}^{(\mathrm{b})}$ \\
\hline 29 & $\begin{array}{c}\text { Mixed } \\
\text { breed }\end{array}$ & - & $\mathrm{F}$ & - & $\mathrm{MG}$ & Osteoblastic & II & No & - & $\mathrm{No}^{(\mathrm{b})}$ \\
\hline 30 & Labrador & 9 & M & - & Liver & Osteoblastic & III & Yes & - & - \\
\hline 31 & Akita Inu & 11 & M & - & Kidney & Chondroblastic & II & No & - & - \\
\hline 32 & Labrador & 9 & M & 38 & ST & Chondroblastic & II & No & - & No ${ }^{(a)}$ \\
\hline 33 & $\begin{array}{c}\text { Mixed } \\
\text { breed }\end{array}$ & 11 & $\mathrm{~F}$ & - & Spleen & Osteoblastic & III & No & - & $\operatorname{Liver}^{(a, b)}$ \\
\hline 34 & $\begin{array}{l}\text { Mixed } \\
\text { breed }\end{array}$ & - & M & - & $\begin{array}{l}\text { Omen- } \\
\text { tum }\end{array}$ & Osteoblastic & II & No & - & Spleen $^{(\mathrm{b})}$ \\
\hline 35 & $\begin{array}{l}\text { Rot- } \\
\text { tweiler }\end{array}$ & 8 & M & 27.2 & ST & Osteoblastic & III & No & - & $\operatorname{Lungs}^{(\mathrm{b})}$ \\
\hline 36 & $\begin{array}{c}\text { Mixed } \\
\text { breed }\end{array}$ & 16 & M & 18.2 & Liver & Osteoblastic & II & No & - & No ${ }^{(b)}$ \\
\hline
\end{tabular}

NI: not informed; F: female; M: male; MG: mammary gland; ST: subcutaneous tissue, ${ }^{\text {(a): }}$ evaluated through imaging exams; ${ }^{(b)}$ : Evaluated through autopsy procedure followed by histopathological examination. 
Figure 1. Gross aspects of extra-skeletal osteosarcoma in dogs. (A and B) Medial side of the right forelimb. A white subcutaneous mass, showing multifocal areas of necrosis and reddening is observed with no bone involvement (Bar, 10 $\mathrm{cm})$. (C) Hepatic osteosarcoma. Left lateral liver lobe showing a large irregular mass, which presents reddish surface and is surrounded by the omentum (Bar, $8 \mathrm{~cm}$ ). (D) Iliac lymph node metastasis from mammary gland osteosarcoma. Lymph nodes are extremely enlarged, and effaced by a multilobulated mass, presenting reddened surface, which compressed the urinary bladder and led to bilateral hydronephrosis (Bar, $5 \mathrm{~cm}$ ).
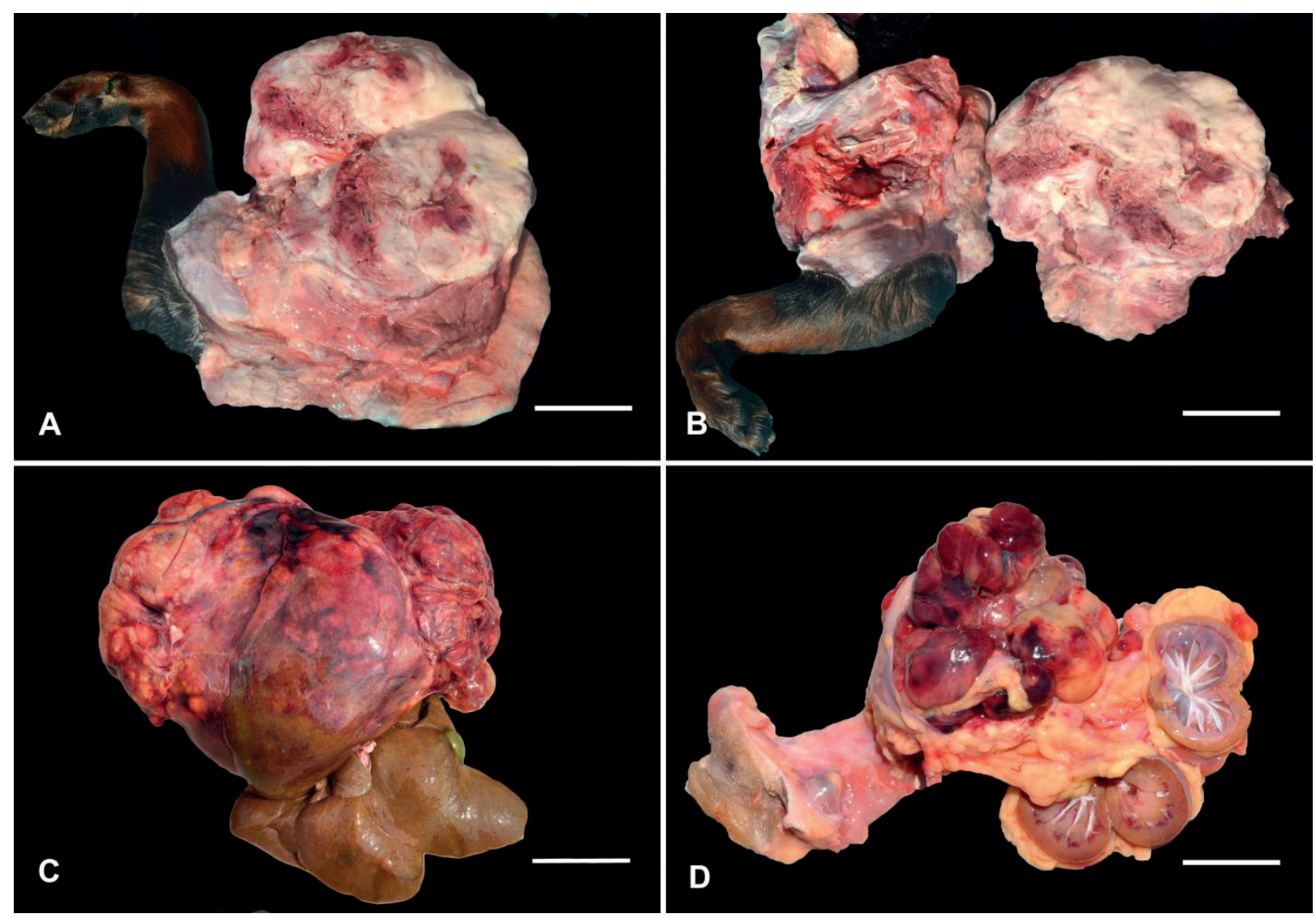

Microscopically,

osteosarcomas

were characterized by proliferation of malign mesenchymal cells, showing osteoblastic differentiation, as well as varying amounts of bone or chondroid matrix, or bone trabeculae (Figure 2A-2D). The neoplastic cells were oval to spindle-shaped, with indistinct cell borders, scant cytoplasm, elongated nuclei, and prominent nucleoli. In some cases, multinucleated giant cells, as well as multifocal areas of mineralization were observed (Figure 2A). Nuclear pleomorphism was considered marked in $91.7 \%$ (33/36) and moderate in $8.3 \%(3 / 36)$ of the tumors. Neoplastic emboli within blood or lymphatic vessels were observed in $19.4 \%(7 / 36)$ of the cases (Figure 2C). In addition, multifocal areas of necrosis were observed in most tumors $(97.2 \% ; 35 / 36)$ and occupied $10 \%$ to $70 \%$ of the neoplastic tissue, with mean of $38 \%$.

Regarding histological type, 61.1\% (22/36) of the extra-skeletal osteosarcomas were osteoblastic, $33.3 \% \quad(12 / 36) \quad$ chondroblastic, $2.8 \% \quad(1 / 36)$ fibroblastic and $2.8 \%$ (1/36) were giant cellrich osteosarcomas. Osteoblastic osteosarcomas presented moderate to marked bone matrix among neoplastic cells; consequently, these tumors were considered productive. When the histological grade was evaluated, $47.2 \%$ (17/36) of the tumors were classified as grade III, 47.2\% (17/36) as grade II, and $5.6 \%(2 / 36)$ as grade I. 
Figure 2. Histologic findings of extra-skeletal osteosarcoma in dogs. Hematoxylin and Eosin stain (HE) (A-D). (A) Hepatic osteosarcoma. Proliferation of neoplastic cells with osteoblastic differentiation is observed associated with abundant bone matrix as well as multifocal areas of mineralization. The adjacent hepatocytes (asterisk) show degeneration and atrophy $(\mathrm{Bar}, 500 \mu \mathrm{m})$. (B) The neoplastic cells are delimited by fibrous connective tissue in a case of splenic osteosarcoma. The adjacent splenic tissue is normal (asterisk). (Bar, 500 $\mu \mathrm{m}$ ). (C) Neoplastic emboli are observed within blood vessels (arrow) in a case productive osteoblastic osteosarcoma of the mammary gland (Bar, $200 \mu \mathrm{m}$ ). (D) Lymph node metastasis in a case of mammary gland osteosarcoma. The lymph node tissue is normal (asterisk). (Bar $500 \mu \mathrm{m}$ ).

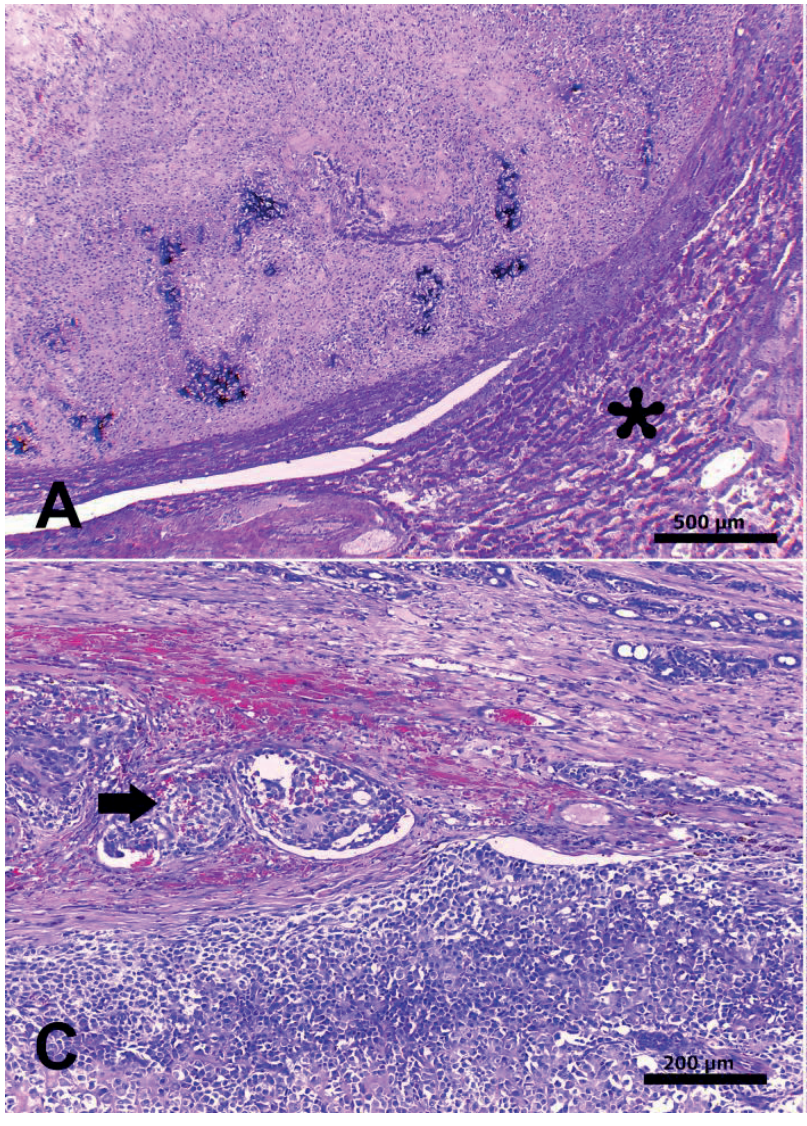

Lymph node metastases from mammary gland osteosarcomas were histologically examined in 14 samples (13 biopsies and 1 autopsy). Lymph node metastases were detected in $21.4 \%(3 / 14)$ of the mammary gland osteosarcomas (Figure 1D and 2D). Distant metastases were evaluated through imaging evaluations (13/36) and autopsy findings (7/36). Distant metastases sites were identified in $23.1 \%(3 / 13)$ of the cases evaluated via imaging diagnostics, in $71.4 \%(5 / 7)$ of the cases during autopsy. Distant site metastases were observed in the lungs $(57.1 \% ; 4 / 7)$, liver $(14.3 \% ; 1 / 7)$, spleen $(14.3 \% ; 1 / 7)$, and multiple sites $(14.3 \% ; 1 / 7)$, which

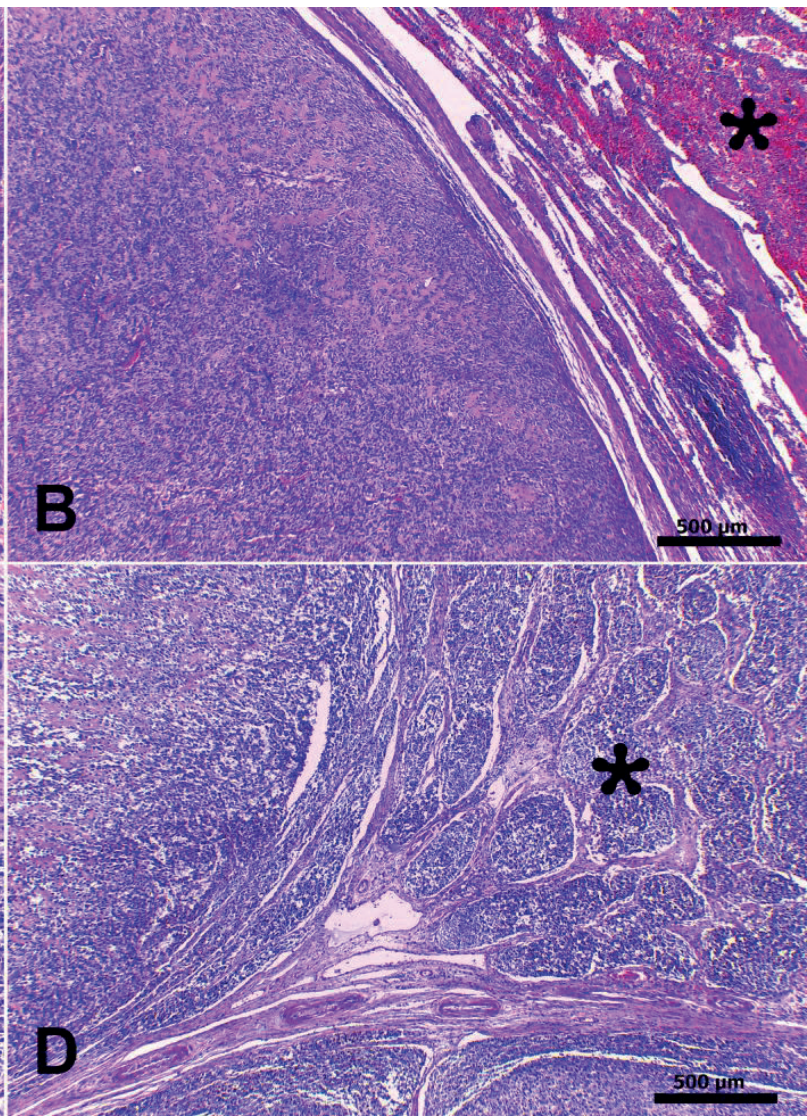

were represented by pancreas and lungs. Most $80 \%(4 / 5)$ of the pulmonary metastases were from mammary gland osteosarcoma. All cases presenting lymph node metastasis (3) were classified as grade III, as well as four out of five cases which present metastases to distant sites, which were confirmed through histopathology or autopsy findings.

\section{Discussion}

Extra-skeletal osteosarcoma is a rare malign mesenchymal neoplasm described in humans and domestic animals (PATNAIK, 1990; LEE et al., 
1995). The percentage of the cases reported in the present study is similar to the findings reported by other authors (LANGENBACH et al., 1998). A significantly lower frequency of extra-skeletal osteosarcomas (1\%) was observed by Patnaik (1990) when compared with extra-skeletal osteosarcomas documented by a previous study (LANGENBACH et al., 1998) and the present study. However, in the study published by Patnaik (1990), no thyroid and mammary gland osteosarcomas were included.

Adult and geriatric dogs were more commonly affected by extra-skeletal osteosarcomas, and the mean age was similar to previous descriptions (9.7 to 11.5 years) (PATNAIK, 1990; KUNTZ et al., 1998; LANGENBACH et al., 1998). Purebred dogs were more affected then mixed breeds; however, no significant predisposition was observed among specific dog breeds, which has also been described by other authors (PATNAIK, 1990; KUNTZ et al., 1998). Extra-skeletal osteosarcomas were diagnosed in dogs of varied body weight, and mean values were similar to previous descriptions $(18 \mathrm{~kg}$ and $23 \mathrm{~kg}$ ) (KUNTZ et al., 1998; LANGENBACH et al., 1998). Although the large and giant dog breeds are more frequently affected by appendicular osteosarcomas (EHRHART et al., 2013), such predisposition was not observed in the present study, as well as in previous similar studies (KUNTZ et al., 1998; LANGENBACH et al., 1998). Female dogs were overrepresented in the present study, which is since mammary gland osteosarcomas were included. However, previous reports have also shown a female predisposition (PATNAIK, 1990; KUNTZ et al., 1998).

Similarly, to previous reports, in the present study the mammary gland was the most commonly affected anatomic site (LANGENBACH et al., 1998). Nonetheless, one study has described the spleen $(6 / 14)$, followed by the mammary gland (3/14) as the most frequently affected sites (KUNTZ et al., 1998). Previous studies have shown that $17.9 \%(19 / 106)$ and $35 \%(37 / 106)$ of mammary gland osteosarcomas were diagnosed in the cranial and caudal abdominal glands (LANGENBACH et al., 1998). Likewise, in the present study, the abdominal mammary glands were overrepresented. This higher occurrence could be related to the larger size of abdominal when compared with thoracic mammary glands (LANGENBACH et al., 1998). Fewer cases of extra-skeletal osteosarcomas were diagnosed in other soft tissues, and the affected anatomic sites were compatible with previous descriptions (KUNTZ et al., 1998; LANGENBACH et al., 1998).

In the present study, a diagnosis of extraskeletal osteosarcomas was achieved through the association of clinical, radiographic, and pathologic findings, and the diagnostic criteria were identical to previous studies (PATNAIK, 1990; KUNTZ et al., 1998). In addition, the bone scintigraphy diagnostic technique may be used when a skeletal tumor is suspected (KUNTZ et al., 1998). Although highly sensitive, bone scintigraphy is considered nonspecific (EHRHART et al., 2013); therefore, it should be used with radiographic examinations and autopsy procedures in suspected cases (KUNTZ et al., 1998).

Osteoblastic and condroblastic osteosarcomas were the most frequent histological variants in the present study, similar findings were described (PATNAIK, 1990; KUNTZ et al., 1998). However, no consensus regarding the histologic classification of extra-skeletal osteosarcomas is available. Some previous studies have used the histological subtypes established for central osteosarcomas (PATNAIK, 1990; KUNTZ et al., 1998; GÂRJOABĂ et al., 2009; WOLDEMESKEL; GRICE, 2011), while others have only classified the tumors based on morphologic criteria (LANGENBACH et al., 1998; HEATH et al., 2003; KALLIANPUR et al., 2013; THOMPSON; DITTMER, 2017). Although, knowledge of the influence of the histologic subtype on the prognosis of affected dogs is lacking, a study evaluating 14 dogs with extra-skeletal osteosarcoma revealed no difference regarding the survival time among different histological subtypes (KUNTZ et al., 1998). 
A previous study has demonstrated an association between survival time and histological grade (KIRPENSTEIJN et al., 2002); however, but grading system is not widely spread among pathologists (THOMPSON; DITTMER, 2017). There are two main histologic grading systems described for osteosarcomas in dogs (KIRPENSTEIJN et al., 2002; LOUKOPOULOS; ROBINSON, 2007); nonetheless greater concordance has been observed with the use of the grading system described by Loukopoulos and Robinson (2007) (SCHOTT et al., 2018). Studies have shown that extra-skeletal osteosarcomas present histological grades varying from II to III, and that tumors at multiple sites showing high histological grade have greater metastatic potential (LOUKOPOULOS; ROBINSON, 2007). These findings are corroborated by the present study.

Metastases to regional lymph nodes are considered rare for skeletal osteosarcomas (HILLERS et al., 2005); but when occur, a poor prognosis is normally expected (HILLERS et al., 2005; THOMPSON; DITTMER, 2017). In our study, lymph node metastases were observed in $21.4 \%$ of the mammary gland osteosarcomas, corroborating with a study that reported metastases in $28 \%$ of mammary gland osteosarcomas (LANGENBACH et al., 1998). However, lymph node metastases were observed in only $4.4 \%$ of the dogs with appendicular osteosarcoma (HILLERS et al., 2005). Consequently, it is possible to infer that mammary gland osteosarcomas have a greater metastatic potential to regional lymph nodes, when compared with osteosarcomas of the appendicular skeleton.

Pulmonary metastases are frequently observed in dogs with skeletal osteosarcoma, and neoplastic dissemination occurs hematogenously (THOMPSON; DITTMER, 2017). Although the distant anatomic locations of extra-skeletal osteosarcoma metastases are commonly described, the lungs are less frequently involved when compared with skeletal osteosarcomas (THOMPSON; DITTMER, 2017). In a previous study, distant site metastases occurred in 64\% (7/11) of the dogs with extra-skeletal osteosarcoma identified by autopsy (PATNAIK, 1990), which is similar to the present findings $(71.4 \% ; 5 / 7)$. Pulmonary metastasis has been described as the main cause of death of dogs affected by mammary gland osteosarcoma (LANGENBACH et al., 1998). The present study corroborates with this finding since pulmonary metastases were more frequent in dogs with mammary gland osteosarcoma.

\section{Conclusion}

Data from the present study suggest that extraskeletal osteosarcoma affects predominantly female dogs with a mean age of 10.4 years. The mammary gland is the most commonly affected site for extra-skeletal osteosarcomas, followed by the subcutaneous tissue, and the liver. In these cases, regional and distant metastases are relatively frequent, primarily in female dogs with mammary gland osteosarcomas. Additionally, grades II and III osteoblastic osteosarcomas are probably the most frequently occurring histologic extra-skeletal osteosarcomas.

\section{Conflict of Interest}

The authors declared no potential conflicts of interest with respect to the research, authorship, and/or publication of this article.

\section{Funding}

Pró-Reitoria de Pesquisa (Propesq/UFRGS) supported this study.

\section{References}

EHRHART, N. P.; RYAN, S. D.; FAN, T. M. Tumors of the skeletal system. In: WITHROW, S. J.; PAGE, R.; VAIL, D. M. Withrow and MacEwen's small animal clinical oncology. $5^{\text {th }}$ ed. St. Louis: Saunders Elsevier, 2013. p. 463-503. 
GÂRJOABĂ, I.; TUDOR, N.; SOARE, T.; TĂNASE, A.; VLĂGIOIU, C. Extraskeletal osteosarcoma in dogs: presentation of two cases. Lucrari StiintificeUniversitatea de Stiinte Agricole a Banatului Timisoara, Medicina Veterinara, Timisoara, v. 42, n. 2, p. 107-110, 2009.

HEATH, S.; RANKIN, A. J.; DUBIELZIG, R. R. Primary ocular osteosarcoma in a dog. Veterinary Ophthalmology, Osney Mead, v. 6, n. 1, p. 85-87, 2003. DOI: 10.1046/j.1463-5224.2003.00256.x.

HILLERS, K. R.; DERNELL, W. S.; LAFFERTY, M. H.; WITHROW, S. J.; LANA, S. E. Incidence and prognostic importance of lymph node metastases in dogs with appendicular osteosarcoma: 228 cases (1986-2003). Journal of the American Veterinary Medical Association, Schaumburg, v. 226, n. 8, p. 1364-1367, 2005. DOI: 10.2460/javma.2005.226.1364

KALLIANPUR, A. A.; GUPTA, R.; MUDULY, D. K.; KAPALI, A.; SUBBARAO, K. C. Osteosarcoma of breast: a rare case of extraskeletal osteosarcoma. Journal of Cancer Research and Therapeutics, Mumbai, v. 9, n. 2, p. 292-294, 2013. DOI: 10.4103/0973-1482.113392

KIRPENSTEIJN, J.; KIK, M.; RUTTEMAN, G. R.; TESKE, E. Prognostic significance of a new histologic grading system for canine osteosarcoma. Veterinary Pathology, Thousand Oaks, v. 39, n. 2, p. 240-246, 2002. DOI: $10.1354 /$ vp.39-2-240

KUNTZ, C. A.; DERNELL, W. S.; POWERS, B. E.; WITHROW, S. Extraskeletal osteosarcomas in dogs: 14 cases. Journal of the American Animal Hospital Association, South Bend, v. 34, n. 1, p. 26-30, 1998. DOI: $10.5326 / 15473317-34-1-26$

LANGENBACH, A.; ANDERSON, M. A.; DAMBACH, D. M.; SORENMO, K. U.; SHOFER, F. D. Extraskeletal osteosarcomas in dogs: a retrospective study of 169 cases (1986-1996). Journal of the American Animal Hospital Association, South Bend, v. 34, n. 2, p. 113-120, 1998. DOI: $10.5326 / 15473317-34-2-113$

LEE, J. S.; FETSCH, J. F.; WASDHAL, D. A.; LEE, B. P.; PRITCHARD, D. J.; NASCIMENTO, A. G. A review of 40 patients with extraskeletal osteosarcoma.
Cancer, Hoboken, v. 76, n. 11, p. 2253-2259, 1995. DOI: 10.1002/1097-0142(19951201)76:11<2253::AIDCNCR2820761112>3.0.CO;2-8

LOUKOPOULOS, P.; ROBINSON, W. F. Clinicopathological relevance of tumour grading in canine osteosarcoma. Journal of Comparative Pathology, London, v. 136, n. 1, p. 65-73, 2007. DOI: 10.1016/j. jcpa.2006.11.005

PATNAIK, A. K. Canine extraskeletal osteosarcoma and chondrosarcoma: a clinicopathologic study of 14 cases. Veterinary Pathology, Thousand Oaks, v. 27, n. 1, p. 4655, 1990. DOI: $10.1177 / 030098589002700107$

SCHOTT, C. R.; TATIERSKY, L. J.; FOSTER, R. A.; WOOD, G. A. Histologic grade does not predict outcome in dogs with appendicular osteosarcoma receiving the standard of care. Veterinary Pathology, Thousand Oaks, v. 55, n. 2, p. 202-211, 2018. DOI: $10.1177 / 0300985817747329$

SLAYTER, M. V.; BOOSINGER, T. R.; POOL, R. R.; DAMMRICH, K.; MISDORP, W.; LARSEN, S. Histological classification of bone and joint tumors of domestic animals. In: SLAYTER, M. V.; BOOSINGER, T. R.; POOL, R. R.; DAMMRICH, K.; MISDORP, $\mathrm{W}$.; LARSEN, S. (Ed.). International histological classification of tumors of domestic animals. $2^{\text {nd }}$ ed. Washington: Armed Forces Institute of Pathology, American Registry of Pathology and World Health Organization, 1994. p. 1-50. v. 1.

SPUGNINI, E. P.; RUSLANDER, D.; BARTOLAZZI, A. Extraskeletalosteosarcoma in a cat. Journal of the American Veterinary Medical Association, Schaumburg, v. 219 , n. 1, p. 60-62, 2001. DOI: $10.2460 /$ javma.2001.219.60

THOMPSON, K. G.; DITTMER, K. Tumors of bone. In: MEUTEN, D. J. Tumors in domestic animals. $5^{\text {th }}$ ed. Ames: John Wiley \& Sons Inc, 2017. p. 356-424.

WOLDEMESKEL, M. W.; GRICE, C. D. Pathology in practice. Journal of the American Veterinary Medical Association, Schaumburg, v. 238, n. 3, p. 297-299, 2011. DOI: 10.2460/javma.238.3.297 